\title{
MORPHOLOGY AND MORPHOMETRY OF CAECA IN THE TUFTED DUCK AYTHYA FULIGULA
}

\author{
EWA DZIAŁA-SZCZEPAŃCZYK ${ }^{1}$ and ANNA CHARUTA ${ }^{2}$
}

\author{
${ }^{1}$ Department of Zoology and Apiculture, Westpomeranian University \\ of Technology, 71-466 Szczecin, 20 Judyma Street \\ Corresponding autor: e-mail: Ewa.Dziala-Szczepanczyk@zut.edu.pl \\ ${ }^{2}$ Department of Vertebrate Morphology, University of Podlasie, 08-110 Siedlce, \\ 14 B. Prusa Street
}

\begin{abstract}
In this study, we examined the caeca of 44 individuals of Tufted Duck (Aythya fuligula): 29 males (23 adult and 6 young) and 15 females ( 8 adult and 7 young). We analyzed the correlations between lengths of left (CLL) and right (CRL) caeca vs. the dimensions of the bird's body: body weight (BW), body length (BL), sternum length (SL) and tarsus length (TL), in relation to the sex of the animals. We also analyzed the asymmetry of caeca and determined its direction and strength, using a fluctuating asymmetry coefficient. Despite the observed sexual dimorphism in the body size, we found neither sex-related differences in the length of caeca, nor any significant correlation between the CLL and CRL vs. body size (BW, BL, SL, TL). 42 birds $(94.5 \%)$ were asymmetrical with respect to the length of caeca, and in $37(84.1 \%)$ the left caecum was longer. The fluctuating asymmetry coefficient for the length of these organs in the examined group was 0.413 .
\end{abstract}

Key words: Tufted Duck, Aythya fuligula, caeca, morphometry

\section{INTRODUCTION}

Caeca occur in about half of the known bird species, and in most of them they are paired. Their structure, shape and function differ greatly between species which is associated with the kind of diet (Leopold, 1953; Pendergast \& Boag, 1973; Miller, 1975, Thomas, 1983; Duke, 1997). Birds can be divided into three categories according to the development of caeca: (1) those with well 
developed caeca, (2) those with moderately developed caeca, and (3) those with vestigial caeca (McLeland, 1989).

The shape and size of caeca display intra-specific variation. This is connected with the sex and age, and the differences in the body size between the individual birds in a population (Miller, 1975; Ankney \& Afton, 1988; Bailey et al., 1997). Moreover, it may depend on the bird's physiological state, breeding period or the presence of parasites. However, the main factor influencing the variation in size and shape of caeca in a population, is diet - its kind, amount of food and the frequency of intake (Kehoe et al., 1988; Baroza \& Jorde, 2002)

Another important issue associated with the presence of two caeca in birds is their asymmetry. Many paired organs in animals are asymmetrical with respect to their size, shape and colour (Swaddle et al., 1994; Teather, 1996). This asymmetry, called a bilateral asymmetry, has three forms: directional asymmetry (where one of the sides always dominates over the other), antisymmetry (where sometimes one side dominates, sometimes the other) and fluctuating asymmetry (the differences are random and are not adaptive in character) (VAN VALEN, 1962).

The fluctuating asymmetry is especially useful in assessing homeostasis (PAlmer, 1982). According to many authors, it can be used as an indicator of developmental stability of the body, and is probably a reflection of the influence of environmental as well as genetic factors (Leary \& Allendorf, 1989; Parsons, 1990, 1992; Clarke, 1995; Bonn et al., 1996; Fair et al., 1999; Satterlee et al., 2000; Grieco, 2003).

The caeca of the Tufted Duck Aythya fuligula, according to the typology used by McLeLAND (1989) belong to the category of well-developed caeca. These sacks, with relatively even diameters over their entire length, are situated opposite the small intestine, with the apices directed towards the head. Their openings are situated in the zone of the small intestine transition into the terminal intestine.

The aim of this paper was to analyze the morphometric characteristics and the asymmetry of the caeca length in the wintering Tufted Duck, in relation to the sex of the birds and their body size parameters.

\section{MATERIAL AND METHODS}

The material used in this study included caeca of 44 birds: 29 males (23 adult and 6 young) and 15 females ( 8 adult and 7 young), caught in the northwestern part of the Polish West Pomeranian voivodeship, in the autumn and winter of 2002-2006. The age of the birds was determined based on the size of the bursa of Fabricius (GLICK, 1983). The examined population was then divided in two groups: immaturus and adultus.

The body size was characterized with four parameters: body weight, body length, sternum length and tarsus length. The body weight (BW) was determined with an accuracy of $10 \mathrm{~g}$. The body length (BL) was measured with a soft band on the dorsal side, from the tip of the beak to the end of the rump with 
an accuracy of $1 \mathrm{~cm}$. The sternum length (SL) and tarsus length (TL) were measured with calipers with an accuracy of $0.5 \mathrm{~mm}$. The linear parameters were measured according to a method proposed by Dzubin \& Соосн (1992). The morphometry of caeca included the length of the left caecum (CLL) and the right caecum (CRL). We analyzed (1) the strength of correlations between the lengths of the caeca and the body size parameters, and (2) the correlations between the lengths of caeca themselves, using Pearson's correlation coefficient.

We also examined the direction and the strength of the asymmetry between the left and right caeca. For this purpose, we determined the significance of differences between the mean lengths of the caeca, separately for each sex and for the whole group of birds, using Student's t-test. The strength of asymmetry was described using the fluctuating asymmetry coefficient FAC $=1-\mathrm{r}^{2}$, where $r$ is Pearson's linear correlation coefficient (VAN VAlen, 1962).

\section{RESULTS}

The results of the measurements of the body size of the examined birds and the sizes of their caeca are presented in Table 1. The mean body weight of the examined birds was $1041 \mathrm{~g}$, and the mean length $331 \mathrm{~mm}$. We observed

Table 1. Differences in absolute body size and caeca parameters between males and females of the Tufted Duck Aythya fuligula, M - males, F - females, $\bar{x}$ - mean, $\mathrm{SD}$ - standard deviation, CV - coefficient of variation, $\mathrm{t}$ - value of t-Student's statistics, NS - statistically insignificant differences, $\mathrm{p}$ - level of significance, BW - body weight ( $\mathrm{g}$ ), BL - body length $(\mathrm{mm})$, SL - sternum length $(\mathrm{mm})$, CLL - left caecum length $(\mathrm{mm})$, CRL - right caecum length $(\mathrm{mm}), \mathrm{CBL}$ - both caecum length $(\mathrm{mm})$

\begin{tabular}{|c|c|c|c|c|}
\hline \multirow[t]{2}{*}{ Measurements } & \multicolumn{3}{|c|}{$\begin{array}{l}\bar{x} \pm \mathrm{SD} \\
\mathrm{CV}(\%)\end{array}$} & \multirow{2}{*}{$\begin{array}{c}\mathrm{M}+\mathrm{F} \\
\mathrm{n}=44\end{array}$} \\
\hline & $\begin{array}{c}M \\
n=29\end{array}$ & $\begin{array}{c}\mathrm{F} \\
\mathrm{n}=15\end{array}$ & M vs. F & \\
\hline $\mathrm{BW}$ & $\begin{array}{c}1070.0 \pm 75.22 \\
7.03\end{array}$ & $\begin{array}{c}986.0 \pm 180.99 \\
18.36\end{array}$ & $\begin{array}{l}t=2.179 \\
p \leq 0.05\end{array}$ & $\begin{array}{c}1041.36 \pm 126.38 \\
12.14\end{array}$ \\
\hline $\mathrm{BL}$ & $\begin{array}{c}323.60 \pm 133.06 \\
41.11\end{array}$ & $\begin{array}{c}344.77 \pm 85.77 \\
24.87\end{array}$ & NS & $\begin{array}{c}330.82 \pm 118.44 \\
35.80\end{array}$ \\
\hline SL & $\begin{array}{c}89,80 \pm 4,58 \\
5.11\end{array}$ & $\begin{array}{c}84.52 \pm 2.02 \\
2.39\end{array}$ & $\begin{array}{c}\mathrm{t}=4.231 \\
\mathrm{p} \leq 0.0001\end{array}$ & $\begin{array}{c}88.0 \pm 4.63 \\
5.26\end{array}$ \\
\hline TL & $\begin{array}{c}34.91 \pm 1.71 \\
4.89\end{array}$ & $\begin{array}{c}34.64 \pm 0.68 \\
1.97\end{array}$ & NS & $\begin{array}{c}34.82 \pm 1.44 \\
4.13\end{array}$ \\
\hline CLL & $\begin{array}{c}133.10 \pm 20.20 \\
15.17\end{array}$ & $\begin{array}{c}132.67 \pm 15.72 \\
11.85\end{array}$ & NS & $\begin{array}{c}132.95 \pm 18.61 \\
13.99\end{array}$ \\
\hline CRL & $\begin{array}{c}121.72 \pm 16.99 \\
13,95\end{array}$ & $\begin{array}{c}116.47 \pm 12.06 \\
10.35\end{array}$ & NS & $\begin{array}{c}119.93 \pm 15.54 \\
12.96\end{array}$ \\
\hline CBL & $\begin{array}{c}254.83 \pm 35.27 \\
13.84 \\
\end{array}$ & $\begin{array}{c}206.0 \pm 25.63 \\
10.29 \\
\end{array}$ & NS & $\begin{array}{c}252.89 \pm 32.11 \\
12.69 \\
\end{array}$ \\
\hline
\end{tabular}


sexual dimorphism in the body size in favor of males. The statistical significance of the sex-related differences was confirmed statistically for two parameters body weight and sternum length.

The examined individuals had well developed caeca (Fig. 1). Their total length ranged between $137 \mathrm{~mm}$ and $319 \mathrm{~mm}(\mathrm{CV}=2.7)$. Their mean total length was $253 \mathrm{~mm}$. Despite the observed difference in the body weight between male and female ducks, we found no significant sex-related difference in the length of caeca. On average, the males had longer caeca than females, but the significance of the differences was not confirmed statistically (Table 1).

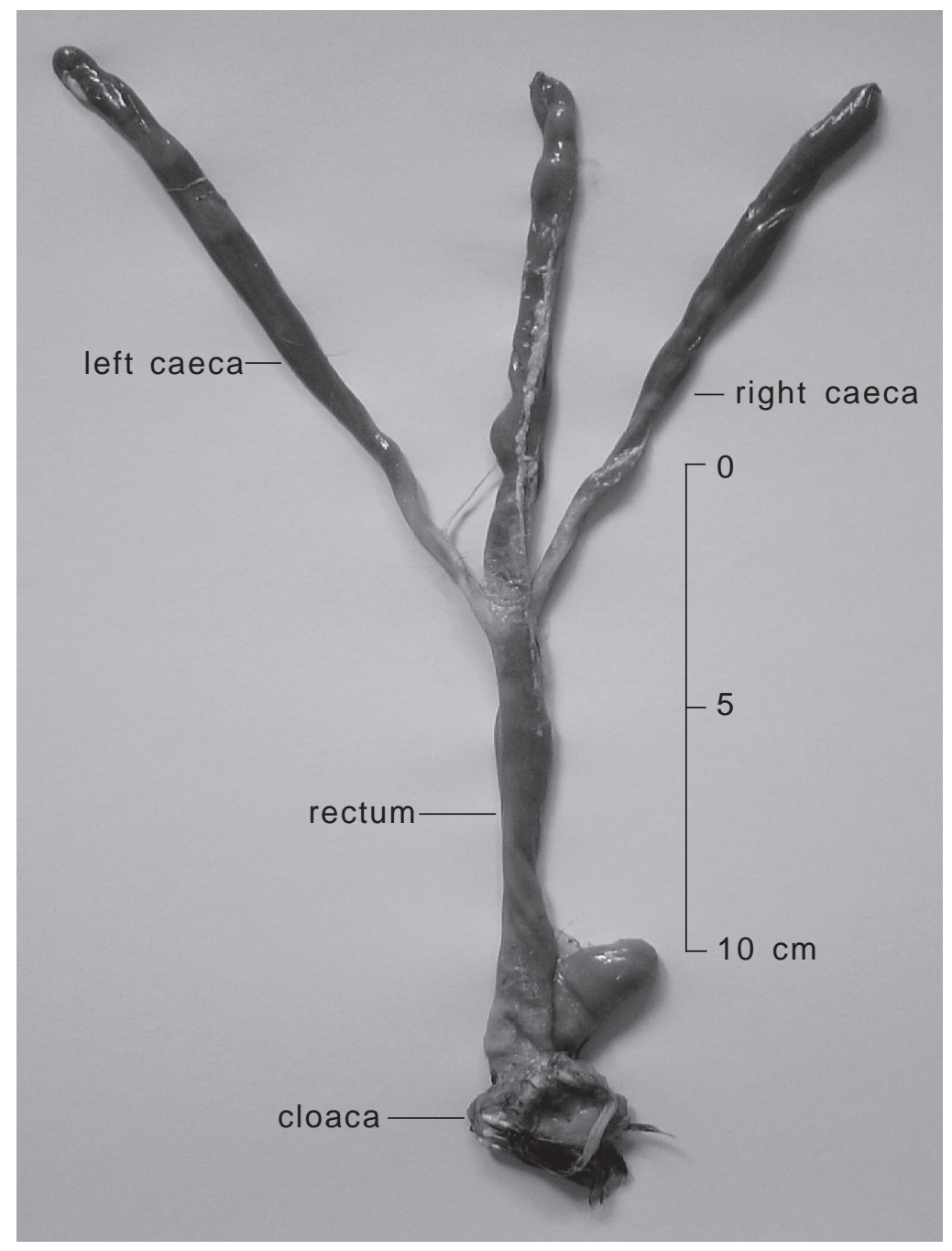

Fig. 1. The caeca of Tufted Duck Aythya fuligula (photo. E. Działa-Szczepańczyk) 
The correlations between the length of caeca and the body size parameters of the ducks are presented in Table 2 . We did not observe any significant relationships between the length of the caeca and the body size parameters.

The examined group of ducks showed a distinct asymmetry in the length and shape of caeca. In all the birds, the differences in the shape of both caeca concerned the diameter on different sections of the organs. In a great majority of the examined group, i.e. 42 birds $(95.4 \%)$, the length of these organs was asymmetrical. The mean length of the left caecum, calculated for the whole group of birds, was $133 \mathrm{~mm}$, and the mean length of the right caecum was 120 $\mathrm{mm}$ (Table 1). In 42 asymmetrical birds the mean difference between the left and right caeca was $14.9 \mathrm{~mm}$. The maximum difference was $40 \mathrm{~mm}$ and the minimum difference was $2 \mathrm{~mm}$. Most of the birds (70\%) showed the difference of above $10 \mathrm{~mm}$. The birds with longer left caecum were distinctly more numerous (37 out of $44,84.1 \%)$. Only two birds had the right caecum longer than the left one, and five had equally long caeca (Table 3 ).

Table 2. Coefficients of correlation for interdependences among measurements of caecum and body parameters in the Tufted Duck Aythya fuligula (* - significant at $<0.05$, ** - significant at $<0.01, * * *$ - significant at $<0.001$, NS - non-significant), for explanation of symbols - see Table 1 .

\begin{tabular}{cccc}
\hline & CCL & CRL & CBL \\
\hline BW & NS & NS & NS \\
BL & NS & NS & NS \\
SL & NS & NS & NS \\
TL & NS & NS & NS \\
CRL & $0.766^{* * *}$ & - & $0.928^{* * *}$ \\
CBL & $0.950^{* *}$ & $0.928^{* *}$ & - \\
\hline
\end{tabular}

Table 3. Asymmetry direction in the caeca length in the Tufted Duck Aythya fuligula (M - males, F - females, ad - adult individuals, im - immature individuals, L - left caecum, P - right caecum)

\begin{tabular}{cccccccc}
\hline & \multicolumn{3}{c}{$\mathrm{M}$} & \multicolumn{4}{c}{$\mathrm{F}$} \\
& $\mathrm{ad}$ & $\mathrm{im}$ & $\mathrm{ad}+\mathrm{im}$ & $\mathrm{ad}$ & $\mathrm{im}$ & $\mathrm{ad}+\mathrm{im}$ & $\mathrm{M}+\mathrm{F}$ \\
& $\mathrm{n}=23$ & $\mathrm{n}=6$ & $\mathrm{n}=29$ & $\mathrm{n}=8$ & $\mathrm{n}=7$ & $\mathrm{n}=15$ & $\mathrm{n}=44$ \\
\hline $\mathrm{L}>\mathrm{P}$ & 20 & 4 & 24 & 7 & 6 & 13 & 37 \\
$\mathrm{~L}<\mathrm{P}$ & 2 & 1 & 3 & 1 & 1 & 2 & 5 \\
$\mathrm{~L}=\mathrm{P}$ & 1 & 1 & 2 & 0 & 0 & 0 & 2 \\
\hline
\end{tabular}


There was a statistically significant difference between the mean length of the left and right caeca in the whole group of birds $(\mathrm{t}=3.563, \mathrm{p} \leq 0.001)$, and also in the group of males $(t=2.322, p \leq 0.05)$ and females $(t=3.166, p \leq 0.01)$. Pearson's correlation coefficient for the relationship between the lengths of both caeca was 0.766 (Table 2). The fluctuating asymmetry coefficient for the lengths of both the examined organs in the whole group was 0.413 .

\section{DISCUSSION}

The mean total length of both caeca in the examined group of ducks was $253 \mathrm{~mm}$. The Tufted Duck Aythya fuligula belongs to the tribe Aythyini, subfamily Anatinae, family Anatidae (DEL Hoyo et al., 1992). Like most representatives of Anatinae (except for the genera Mergus and Melanitta), it has well developed caeca (McNab, 1973; McLeland, 1989; Clench \& Mathias, 1995). The size of the caeca in birds may be associated with both the body size and diet. In the inter-species comparisons of 12 representatives of the order Galliformes, a positive correlation was found between the length of caeca and the birds' body weight (Remington, 1989).

Also Thomas (1984) in his studies on tetraonids (Tetraonidae) showed that the size of caeca in these birds correlated positively with the body weight. The author pointed out that it was crucial to determine to what extent the differences between the species were due to the diet and to what extent they resulted from the differences in body size. The comparisons across the species of Anatidae suggest that the size of caeca in this group of birds depends mainly on the kind of food they eat, and to a lesser extent on the body size. The studies by BARNES \& Thомаs (1987), involving 12 species of Anatidae showed that predatory species had lighter caeca than the omnivorous and herbivorous ones.

The Tufted Duck's weight ranges from $1000 \mathrm{~g}$ to $1400 \mathrm{~g}$ (DEL Hoyo et al., 1992). The duck is omnivorous - it eats both plant and animal food (OlNEY, 1963; Draulans, 1987, 1987; Ока et al., 1999). Its diet comprises seeds and green parts of water plants, and molluscs (mainly Mytilus, Cardium and snails), crustaceans, and water insects obtained during diving and from the water surface (Hoyo et al., 1992). Kenoe \& Ankney (1985) in their study on five species of ducks of the genus Aythya observed a correlation between the content of fiber in their diet and the length of caeca. Similarly to Galliformes, species with a diet rich in fiber had their caeca longer than species with a smaller content of fiber in their diet (Kenoe \& Ankney, 1985).

In the examined group of ducks we observed a wide intra-specific variation of the length of caeca. The total length of these organs ranged from 137 to 319 $\mathrm{mm}$. The differences could be associated with both body size and diet (seasonally changing availability of food and other factors related to the species' biology, e.g. migration, moulting or breeding time) (Miller, 1975, 1976; Pendergast \& Boag, 1973; Du Bowy, 1985; Ankney \& Afton, 1988).

The examined ducks were caught during their wintering from November to April. During that period, they ate mainly animal food; a diet more condensed and 
calorific than the summer diet, which comprised more plant material. The winter diet could significantly contribute to the morphology of the digestive organs, including the length of caeca. Moreover, the duration of wintering varied among the examined birds - some were obtained in the first months of winter, and some in the final months. Hence the period with mainly animal diet varied in the examined group, which could influence the observed differences in the length of caeca.

In the examined group of ducks we did not observe any sex-related differences in the length of caeca, though the differences between the body weight of male and female ducks were statistically significant. Similar results were obtained for wintering Velvet Scoters Melanitta fusca and Long-tailed Duck Clangula hyemalis, in which no significant sex-related differences in the weight of caecum were found (DzIAla-SzczepańCZyK, 2005, 2006). Also in a study by SZCZEPAŃCZYK et al. (1999) on 42 individuals of White-fronted Goose Anser albifrons, no differences in the caecum length between the males and females were found. In the case of 64 individuals of Bean Goose Anser fabalis the dimorphic differences in the relative length of the two caeca, i.e. their length in relation to the body weight, were not significant (SzCZEPANCZyK et al., 2000). Two omnivorous Gruiformes - Hubara Chlamydotis undulata and Bustard Ardeotis kori (BAILEY et al., 1997) - were found to display sex-related dimorphism in the total length of caeca. The caeca of males of both these species were longer than in females; the difference was statistically significant $(p<0.05)$ and was not connected with the body weight differences between the sexes. Paulus (1982), in his study on wintering Gadwalls Anas strepera, showed differences in the length of caeca between males and females, but he did not examine the statistical significance of the differences. The differences in the length of caeca between the males and females may be caused by the differences in the body size and different dietary preferences during various seasons. BENGTSON (1971), in his study on 72 individuals of Tufted Duck during their breeding season observed significant qualitative differences in the diet between males and females; the differences were associated with different foraging abilities in the same season. The proportion of mosquito larvae in the diet of females was much higher than in the diet of males. Males ate more snails of the genus Lymnea (Bengtson, 1971).

Moreover, the difference in dietary preferences can also concern the size of the food items. Wintering males of Tufted Duck were observed to prefer larger bivalves, compared to those eaten by females (Ока et al., 1999). Also Draulans's (1982) experiments on Tufted Ducks kept in captivity confirmed distinct differences in the choice of the size of Zebra mussel Dreissena polymorpha between the males and females.

The experiment by BAROZY \& JARDE (2002) carried out in winter on the Black Duck Anas rubripes, examining the effect of food intake frequency on the morphological characteristics of the digestive tract, showed that the outer surface of the caeca was changing differently in males and females. It decreased distinctly less drastically in females in comparison with males, in relation to the decrease in food intake frequency (BAROZA \& JARDE, 2002). 
The lack of dimorphism in the caecum length in the group of birds examined in this study could result from the fact that the birds were obtained in the winter. During winter, both males and females eat a similar kind of food and forage with a similar intensity. Moreover, the obtained results may be associated with the duration of wintering.

In the examined group of ducks we observed no significant correlation between the length of both caeca vs. all the examined body size parameters. Likewise, in the experiment on 140 individuals of the Long-tailed Duck Clangula hyemalis no significant correlations were found between the length and weight of caeca vs. the body weight and length and sternum length (DZIAŁA-SZCZEPAŃCZYK, 2006). Similarly, 58 wintering individuals of the Velvet Scoter Melanitta fusca showed no statistically significant correlations between the length of caeca vs. the body weight and length and sternum length (Dziaza-SzczepańczyK, 2005). The study on the Bean Goose Anser fabalis, revealed no statistically significant correlations between the length of caeca vs. body size parameters (body weight, body length and tarsometatarsus length) (SzCZEPAŃCZYK et al., 2000). The lack of correlation between the length of caeca and the body size parameters in Anseriformes may be due to the role of these organs in the digestive process in these birds. Miller (1975) points out that the caeca of water birds react so fast to the changes in the diet that their length cannot be a good indicator of the dietary habits of the birds.

In $95.4 \%$ of the examined ducks we observed an asymmetry in the length of the caeca: in $84.1 \%$ the left caecum was longer. A similar asymmetry was found in other bird species. In 15 Red-neck Grebe Pediceps griseigena the left caecum was longer; on average it was by $18 \%$ longer, and the difference was statistically significant (SZCZEPAŃCZYK, 1999). In the Velvet Scoter, the left caecum was longer in 50 birds out of 54 (DZIAŁa-SzCZEPańczyK, 2005). The left caecum was longer in $90.7 \%$ of the 140 individuals of Long-tailed Duck, and was heavier in $82.1 \%$ birds (DZIAŁA-SZCZEPANCZYK, 2006). On the other hand, in two studies on two different species of geese, in most of the birds the right caecum was longer. $62 \%$ In the White-fronted Goose Anser albifrons $62 \%$ of individuals, and in the Bean Goose Anser fabalis 59\% had their right caecum longer (SZCZEPAŃCZyk et al., 1999; SZCZEPAŃCZYK et al., 2000). In a study by SitNa (1965), over half of the examined specimens of the Black Coot Fulica atra had a longer left caecum. The fluctuating asymmetry coefficient for the length of caeca in the Tufted Duck, which was 0.413, was similar to that obtained for the Long-tailed Duck Clangula hyemalis - 0.472 (Dziata-SzczepanczyK, 2006). In the Velvet Scoter Melanitta fusca, the FAC for the caeca was 0.737 (DzIAŁASZCZEPAŃCZYK, 2005), and in the Common Scoter Melanitta nigra it was 0.368 (Dziala-Szczepańczyk \& Betlejewska, 2003). The differences could be caused by the differences in the sample, different dietary habits of these two species, and exposure to different environmental factors. Moreover, the asymmetry in the morphology of their caeca could concern parameters other than length; namely capacity, weight and shape. 


\section{CONCLUSIONS}

Despite the observed sexual dimorphism in the body size of the examined Tufted Duck, no such dimorphism was observed in the length of caeca.

No significant correlation was found between the lengths of the two caeca vs. body size parameters.

The great majority of the examined birds $(94.5 \%)$ displayed asymmetry in the length of caeca. The left caecum was longer in $84.1 \%$ of the birds.

The fluctuating asymmetry coefficient for the length of these organs in the examined birds was 0.413 .

\section{MORFOLOGIA I MORFOMETRIA JELIT ŚLEPYCH CZERNICY AYTHYA FULIGULA}

\section{STRESZCZENIE}

Jelita ślepe ptaków, podobnie jak pozostałe elementy budowy układu trawiennego, cechuje duża wewnątrzgatunkowa zmienność morfologiczna. Zmienność ta ujawnia się między innymi w wielkości, kształcie, barwie tych organów i uwarunkowana jest przede wszystkim dietą zwierząt. U gatunków, które posiadają dwa jelita ślepe, zmienność międzyosobnicza przejawia się również w dysproporcji budowy obydwu tych organów. Celem pracy była charakterystyka morfologiczna i morfometryczna jelit ślepych oraz analiza asymetrii długości tych organów u 44 osobników zimujących czernic Aythya fuligula. Badano związki zachodzące między długością jelit ślepych - lewego i prawego a czterema parametrami charakteryzującymi wielkość ciała ptaków (masą i długością ciała, długością mostka i długością kości skokowej) w powiązaniu z płcią ptaków. Asymetrię długości jelit ślepych analizowano wyznaczając współczynnika asymetrii fluktuacyjnej. Mimo stwierdzonego dymorfizmu płciowego w wielkości ciała ptaków nie wykazano go w odniesieniu do długości jelit ślepych. Nie odnotowano również istotnego związku między długością obydwu jelit ślepych lewego i prawego a pomiarami opisującymi wielkość ciała ptaków. Zdecydowana większość osobników (94,5\%) miała asymetryczne pod względem długości jelit ślepe, przy czym 37 osobników $(84,1 \%)$ miało dłuższe jelito ślepe lewe niż prawe. Współczynnik asymetrii fluktuacyjnej dla długości tych organów osiągnął w badanej grupie czernic wartość 0,413.

\section{REFERENCES}

Ankney, C.D. and Afton, A.D., 1988: Bioenergetics of breeding Northern Shovelers: diet, nutrient reserves, clutch size, and incubation. Condor 90: 459-472.

Bailey, T.A., Mensah-Brown, E.P., Samour, J.H., Naldo, J., Lawrence, P. and Garner, A., 1997: Comparative morphology of the alimentary tract and its glandular derivatives of captive bustards. J. Anat. 191: 387-398.

Barnes, G.G. and Thomas, V.G., 1987: Digestive organ morphology, diet and guild, structure of North American Anatidae. Can. J. Zool. 65: 1812-1817.

Barboza, P.S. and Jorde, D.G., 2002: Intermittent casting during Winter and spring affects body composition an reproduction of migratory duck. J. Comp. Physiol. B 172: 419-434. 
Bengtson, S.A., 1971: Food and Feeding of diving ducks breeding at Lake Myvatn, Iceland. Ornis Fennica 48: 77-92.

Clarke, G.M., 1995: Relationships between developmental stability and fitness: Application for conservation biology. Cons. Biol. 9: 18-24.

Clench, M.H. and Mathias, J.R., 1995: The avian cecum: Wilson Bull., 107(1): 93-121.

Draulans, D., 1982: Foraging and size selection of mussels by the Tufted Duck, Aythya fuligula. Journal of Animal Ecology 51: 943-956.

Draulans, D., 1987: Do Tufted Duck and Pochard select between differently sized mussels in a similar way? Wildfowl 38: 49-54.

Duke, G.E., 1997 Gastrointestinal physiology and nutrition in wild birds. Proceedings of the Nutrition Society 56(3): 1049-1056.

Dziąa-Szczepańczyk, E. and Betlejewska, K., 2003: Morphology and morphometry of caeca in the Black Scoter Melanitta nigra. Electronic Jurnal of Polish Agricultural Universities seria Biology Vol. 6, 2003 http://www.ejpau.media.pl/volume6/issue2/biology/art-07.html

Dziala-SzczepańczyK, E., 2005: Size and asymmetry of caeca in the Velvet Scoter Melanitta fusca wintering the Polish Baltic coast. Scientific Messenger of Lviv National Academy of Veterinary Medicine named after S.Z. GzhYTsKy Tom 7, 3 (26): 203-210.

Dziala-SzcZepańczyK, E., 2006: Morphometric characteristic of the caecum in longtailed ducks Clangula hyemalis wintering on the Polish Baltic coast. Electronic Jurnal of Polish Agricultural Universities seria Biology Vol. 9, 2006 http://www.ejpau.media.pl/series/volume9/issue4/art-40.html

Dzubin, A. and Cooch, E., 1992: Measurement of Geese: General Field Methods, California Waterfowl Association. Sacramento, CA 20pp.

Fair, J.M., Hansen, E.S. and Ricklefs, R.E., 1999: Growth, developmental stability and immune response in juvenile Japanese quails (Coturnix coturnix japonica). Proceedings of the Royal Society - Biological Sciences (Series B) 266: 17351742.

Glick, B. 1983: Bursa of Fabricius. In: Farner D.S., King J.R., Parkes K.C., Avian biology, Volume VII Academic Press London.

Grieco, F. 2003: Greater food availability reduces Tarsus asymmetry in nestling Blue Tits. Condor 105: 599-603.

Hoyo, J., del Eilliott, A. and Sargatal, J., 1992: Handbook of the Birds of the World. Barcelona.

Kehoe, F.P. and Ankney, C.D., 1985: Variation in digestive organ size among five species of diving ducks (Aytha spp.). Can. J. Zool. 63: 2339-2342.

Kehoe, F.P., Ankney, C.D. and Alisaushas, R.T., 1988: Effect of dietary fiber and diet diversity on digestive organs of captive mallards (Anas platyrhynchos). Can. J. Zool. 66: 1597-1602.

Leary, R.L. and Allendorf, F.W., 1989: Fluctuating asymmetry as an indicator of stress: Implications for conservation biology. Tree 4(7): 214-217.

LEopold, A.S., 1953: Intestinal morphology of gallinaceus birds in relation to foods habits. J. Wildl. Mgmt. 17: 197-203.

McLelland, J., 1979: Digestive system. In Form and Function in Birds, pp.69-181 [A.S. King and J. McLelland, editors]. London: Academic Press.

McLelland, J., 1989: Anatomy of the avian caecum. Journal of Experimental Zoology, Supplement 3: 2-9. 
McNab, J.M., 1973: The avian caeca: A review. Wid's Poult. Sci. J., 29: 251-263.

Miller, M.R., 1975: Gut morphology of mallards in relation to diet quality. J. Wildl. Manage. 39(1): 168-173.

Miller, M.R, 1976: Cecal fermentation in mallards in relation to diet. Condor 78: 107-111.

Oka, N., Yamamuro, M., Hiradsuka, J. and Satoh, H., 1999: Habitat selection wintering tufted duck with special reference to their digestive organ and to possible segregation between neighboriong populations. Ecological Research 14: 303-315.

Olney, P.J.S., 1963: The food and feeding habits of tufted duck Aythya fuligula. Ibis 105: $55-62$.

Palmer, A.R. and Strobeck, C., 1986: Fluctuating asymmetry: measurements, analysis, patterns. Ann. Rev. Ecol. Syst. 17: 391-421.

Palmer, A.R., 1996: Waltzing with Asymmetry. Is fluctuating asymmetry a powerful new tool for biologist or just an alluring new dance step? BioScience 46(7): 519-532.

PAulus, S.L., 1982: Gut morphology of Gadwalls in Louisiana in winter. J. Wildl. Manage. 46(2): 483-489.

Parsons, P.A., 1990: Fluctuating asymmetry: an epigenetic measure of stress. Biol. Rev. 65: $131-145$.

PARsons, P.,A., 1992: Fluctuating asymmetry: a biological monitor of anvironmental and genomic stress. Heredity 68: 361-364.

Pendergast, B.A. and Boag, D.A., 1973: Seasonal changes in the internal anatomy of spruce grouse in Alberta. Auk 90: 307-317.

Remington, T.E., 1989: Why Do Grouse Have Ceca? A Test of the Fiber Digestion Theory. J. Exper. Zool. Suppl. 3: 87-94.

Satterlee, D.G., Cadd, G.G. and Jones, R.B., 2000: Developmental instability in Japanese quail genetically selected for contrasting adrenocortical responsiveness. Poultry Science 79: 1710-1714.

Swaddle, J.P., Witter, M.S. and Cuthill, I.C., 1994: The analysis of fluctuating asymmetry. Anim. Behav. 48: 986-989.

SZCZEPAŃCZYK, E.1999: Morphometry and morphology of the digestive canal in the Red-Necked Grebe Podiceps griseigena. Zesz. Nauk. Przeg. Hod. PTZ (Scientific Fascicles Breeding Review Polish Zoological Society) 45: 99-109 (in Polish with English summary).

Szczepańczyk, E., Kalisińska, E., Ligocki, M. and Bartyzel, B., 1999: Morphometry of gut in the White-fronted Goose Anser albifrons. Adv. Agr. Scien. 6: 79-90.

SzczepańczyK, E., Kalisińska, E., Ligocki, M. and Bartyzel, B., 2000: Morphometry of esophagus and gut in Bean goose Anser fabalis. Zool. Poloniae 45/1-4: $37-46$

Teather, K., 1996: Patterns of growth and asymmetry in nestling Tree Swallows. Journal of Avian Biology 27: 302-310.

Thomas, D.H., 1984: Winter diet and intestinal proportions of rock and willow ptarmigan and sharp-tailed grouse in Ontario. Can. J. Zool. Vol. 62.

VAn Valen, L., 1962: A study of fluctuating asymmetry. Evolution 16: 125-142. 